of the whare-whakairo, or large communal assembly hall, is of considerable interest. The book is well illustrated, and the note on Maori pronunciation is welcome, but an index is lacking. The get-up of the book is a credit to the New Zealand firm which publishes it.

\section{THE ATTITUDE OF DIPLODOCUS.}

SINCE Mr. Carnegie gave a plaster cast of the skeleton of Diplodocus to the British Museum in 1905, he has distributed other copies of this remarkable Dinosaur to the museums of Paris, Berlin, Vienna, and Bologna. A large part of an actual skeleton was also given by the late Mr. Morris K. Jessup to the Senckenberg Museum in Frankfurt. A widespread interest has thus been aroused in the gigantic Sauropodous Dinosauria, and there have been many discussions as to their original form and mode of life.

When the late Profs. Marsh and Cope first obtained nearly complete skeletons of these reptiles, they compared the limbs with those of an elephant, and decided that the creatures must have walked in a quadrupedal manner, with the body well raised above the ground. Considering their immense weight, the position of their nostrils on the highest point of the head, and the feebleness of their dentition, which seems to imply a succulent food, the professors were agreed that the animals must have spent much of their lite under water. Prof. Cope also supposed that the long neck, which characterises all the Sauropoda, would enable them to reach the surface to breathe while browsing on watetweeds in a considerable depth of water. It is now generally admitted that the theory of their semiaquatic mode of life is well founded, and it has been observed that the feeble teeth are not placed in close series, but separated by small gaps, as if they formed a strainer for the food which was taken in. Much difference of opinion, however, has arisen as to the attitude of the limbs.

Messrs. Hatcher and Holland, who prepared the cast of Diplodocus, and Prof. H. F. Osborn, who mounted a skeleton of Brontosaurus in the American Museum at New York, followed Marsh and Cope in arranging the limbs for a quadrupedal walking gait. Dr. O. P. Hay, of Washington, on the other hand, subsequently maintained that the limbs must have been bent, like those of a crocodile, for crawling, and last year Mr. Gustav Tornier, of Berlin, elaborated this theory. publishing a somewhat fantastic sketch of the skeleton as he would arrange it. Prof. $O$. Abel, of Vienna, has now prepared an interesting summary of all these discussions. and finally concludes that the attitude of Diplodocus and its allies, with which the restorations have made us familiar, is really the correct one.

Prof. Abel begins his paper by deploring the fact that most museums restore the skeletons of extinct animals, partly by hypothetical plaster-work, partly by using the bones of more than one individual, without any clear explanation on the labels. He has, therefore, taken the trouble to state exactly the nature of the materials from which the well-known cast of Diplodocus carnegii was made, and he has no serious fault to find with its general composition. It is possible that two or three vertebræ are lacking, and part of the tail may not be sufficiently stout, otherwise there is little to criticise. He thinks that the axis of the head is in direct line with that of the neck, as usual in reptiles, and that the browsing attitude is due to the natural curvature of the end of the neck. $\mathrm{He}$

1 "Die Rekonstruktinn des Niplodocus." By O. Abel. Abhandt. k.k. 70ol.-botan. Ges. in Wien. Bd v.. Heft 3. Pp. 6o+Tafel 3. (Jena: G. Fischer, 1910.) Price 2.40 marks.

$$
\text { No. } 2 \text { I } 43 \text {, VOL. } 85 \text { ] }
$$

points to the deeply ovate cross-section of the trunk as showing that it is not adapted for crawling along the ground. but must have been lifted during locomotion. He then discusses the structure of the feet in detail, and demonstrates that they are digitigrade, the fore feet more so than the hind feet. As in Iguanodon (of which footprints show the impressions) there must have been elastic pads beneath the toes, and most of the weight of the body seems to have been supported by those below the reduced outer toes. The structure of the digitigrade feet necessitates nearly upright limbs, which would support the trunk and give the reptile a true walking gait. There would be a slight outward bend of the elbow, but otherwise no sprawling attitude. The Sauropoda, therefore, form no exception to the rule, that the extinct Dinosaurs resembled mammals and birds in their habits and movements.

\section{THE PROTECTION OF NATURE.1}

"I $\mathrm{T}$ is the first time a verv comprehensive attempt has been made to do important public service of this character on purely non-partisan lines. . . . It is indeed a great work. We have here the first Commission of the kind ever established by a National Government. . . ." Thus the Hon. Clifford Sifton, chairman of the Commission for the Conservation of the Natural Resources of Canada, at the conclusion of the Commission's first annual meeting, held in January of this year.

The establishment of this Commission is a noteworthy departure, and is actually a method of insuring the future prosperity of the country. Canada is peculiarly amenable to such a step, as large areas of her land are in the hands of the Government, and also peculiarly in need of it. The latter point is obvious when it is remembered that owners of timber property are only just beginning to assimilate the idea of afforestation, that lumbermen are constitutionally destructive, and that forest fires are not an occasional catastrophe, but seasonally recurring and accepted phenomena. In England we hardly realise this last fact, or the destruction produced by a forest fire. The following statement gives a glimpse of the reality :- "The spring fires are not, as a rule, so dangerous to the forests, as they are what we call leaf fires, while the fall fires are soil fires. The leaf fire will run through the woods, and while it destroys a lot of timber, it does not have the same effect as a fire in the fall, because that not only takes the leaves and wood, but it takes the soil as well, and burns doann five feet, so that for a thousand years nothing will grow on that land." (My italics.) It appears that railway locomotives cause the majority of these devastating conflagrations.

Destruction without perpetuation has been carried on in other departments. "In the Yukon there are," savs Mr. Congdon, "hundreds of square miles where I do not think you could now find a single fur-bearing

I First Annual Report of the Commission of Corservation, Canada. Py courtesy of the High Commissione- for Canada, 17 Victoria Street, London. (Ottawa. The Mortimer Co.. soro.)

Mitteilungen des Provinzialkomitees für Naturdenkmalpflege. Schleswig. Holsteinischen, No. I (I909); Pommerschen, No. 2 (I9I0); Sächsischen, No. I (ro08); Westrreussischen, Nos. I, 2, 3 (1908-10); und des Bezirkskomitees Regierungsbezirk Sigmaringen, No $x$ (rgog); Cassel und Waldeck Nos. $7,2(1008-9)$

Naturdenkmalpflege und Aquarienkunde. By R. Hermann and $W$ Wolterstorff. (Brunswick. roog.)

Naturdenkmalpflege. By Prof. Gürich, (Sorderabdruck aus der Zeitsck. ift der Landwirtschaftskammer für die Provinz Schlesien, rgog.)

Üter Zeil u. Methode der Naturdenkmalpflege. By Prof. Dr. B. Sr haefer-Cassel. (Schmalkalden, Igog.)

Über das Tierleben in dem von der Staatsforstverwaltung geschützten Uber das Tierleben in dem von der Staatsforstverwaltung geschützten
Zwergbirken.Monr in Nenlinum. By Dr. Th. Kuhlgatz. (Sonderabdruck Zwergbirken-Monr in Nenlinum. By Dr. Th. Kuhlgatz. (Sonderabdruck
aus dem 32, Bericht des Westoreussischen Botanisch-Zoologischen Vereins, Danzig, 19 io )

Neues aus der Naturdenkmalf flege. By Dr. W. Günther. (NaturwisNeues aus der Naturdenkmalf fiege. By Dr. W.
senschaftliche Wcchetschrift, August 7 , t910; Jena.) 
animal. They have been absolutely exterminated by hunting, trapping, or by the decrease of the foodsupply which occurred in the years 1904-5." An interesting cause is the disappearance of the rabbit. In 1904-5 "some disease smote the rabbits, and they died off by thousands." "In consequence of their disappearance, the animals which fed on them-the fox (the wolf, which need not be counted), the marten, the chief food of which, however, is mice, and other animals-died from absolutely no other cause than starvation." The problem of the conservation of the water supply is curiously bound up with afforestation. For instance, it has been found necessary to conserve the timber on the east slopes of the Rockies in order to conserve the river-heads. "It was shown that the destruction of the imber meant the disappearance of the regular water supply of those provinces, the agricultural production of which is the pride and the hope of Canada."

A list of the committees shows the scope of the Commission. They are seven in number, viz. :Fisheries, game, and fur-bearing animals; forests; lands; minerals; waters and water powers; public health; press and cooperating organisations. Their reports on the first year's work, the chairman's speech, and the discussions are of unusual interest. Recommendations to Government have already commenced. Such a scheme for the scientific control of the ulitimate natural resources of a country must inevitably be adopted elsewhere.

It has, however, one serious deficiency as yet, the absence of any organisation for the preservation of those sites and objects that have no commercial value, but the scientific and artistic importance of which is very great. Such conservation could easily be worked in with the main business. The latest reports of the committees for this special purpose in Germany are to hand. There are official directions giving the least injurious method of picking flowers. Every district seems to be thoroughly looked after and studied by its committee. There are verv interesting maps of the habitats of rare plants, and studies of typical fauna, such as that by Dr. Kuhlgatz, on the animal life of the moors in Neulinum. Reference to maps shows that the districts preserved are remarkably numerous. The movement is not merely governmental, but aims at enlisting the sympathetic cooperation of the people. The propaganda is now being extende: to the schools, and Prof. Schaefer-Cassel has an eloquent address on the subject. Cases for the "pillory" are recorded, as, for instance, that of a man who in a few vears annexed 900 specimens of Cypripedium calceolus. This flower, once found near Settle, in Yorkshire, and perhaps in one or two other sites, has now, I understand, disappeared from this country. The same fate will attend many a rare plant, butterfly, or bird, unless we, too, adopt some system of preservation. The Wild Birds' Protection $A c t$, it is to be feared, is a dead-letter.

If we had a national commission for the protection of all "monuments of nature," including beauty spots, places interesting for historic or geological reasons, woods, valleys, and hills remarkable for some species of plant, animal, or insect, we should not be a "nation of shopkeeners." But is the United Kingdom too far exploited for a commission for the protection of its natural resources, including its natural history? There would be difficulties in the way, but surmountable difficulties. One very obvious fact presents itself at once-these places of beauty, these habitats of species (bv no means useless for the ends of commerce, since thev subserve the ends of science), are precisely those which defy culture and would never make it worth while. To make them into natural museums would be a work for which future generations would be more NO. 2 I43, VOL. 85$]$ grateful than we can realise. The museum of brick and stone has its uses; zoos and botanical gardens are of no little value; but neither can compare, either for interest or for scientific study, with a reservation. Not only Germany, but Australia, is setting an example here. Dr. Conwentz's book, recently published in England, and an excellent article by Dr. Günther in the Naturwissenschaftliche Wochenschrift of August 7 last, give a luminous exposition of the principle and its results.

In time perhaps the world will be full of such spots, where nature may have her Sabbaths and preserve her most interesting children, among whom, last but not least, will be aboriginal varieties of man himself. Is there not a reservation for the tribes of Central Australia?

A. E. Crawley.

\section{AGRICULTURE IN THE DRY REGIONS OF} THE BRITISH EMPIRE.

THE ordinary farm crops on which the supply of food-stuffs depends seem to be produced best in regions where the rainfall varies between 20 and 35 inches per annum. Where the upper limit is exceeded in the British Islands, a good deal of pasture is found; on the other hand it is notable that the great wheat-producing districts, the eastern counties, are regions where the rainfall comes nearer to the lower limit. Special agricultural methods become necessary where there is less than 20 inches of rain, as is the case over large areas in Canada, Australia, India and South Africa. These methods fall into two groups: irrigation is required if there is less than Io inches of rain, while special cultural operations, collectively known as "dry farming," are used when there is as much as 15 or more inches. Between io to 15 inches, sometimes the one and sometimes the other method proves the more economical.

"Dry-farming" methods are of great interest to the student of soil physics. Their object is to keep the rair water near the surface of the soil and to prevent loss by evaporation, by surface drainage, and, if possible, by percolation. A remarliable degree of success appears to be attained. An examination of the methods in vogue in different parts of the world shows that all have certain features in common. The land is ploughed up in a rough state and the subsoil compacted directly after harvest or before the rainy season, if there is one; in countries where the rain is unevenly distributed and torrential downpours occur. rather elaborate terracing is arranged to prevent any loss by running off the surface; any streams that form having to follow a sinuous course over the whole field, so that absorption may be as complete as possible. Directly the rain is over, the surface soil is thoroughly stirred, thereby losing a little water by evaporation, but forming a loose layer. The water is thus imprisoned between the compacted subsoil and the thin loose layer of surface soil. The greatest importance is everywhere attached to the maintenance of this loose laver on the top; cultivation is repeated as often as rain has fallen, or whenever for any other reason it is considered the laver has become compact. Incidentally this repeated cultivation has the effect of keeping down weeds, which, if unchecked, would use up a good deal of the water.

In the dry parts of Canada and the United States, where these methods are most highly developed, it is customary to take a crop-usually wheat-once in two years onlv, leaving the land fallow in the alternate year. It is considered that two-thirds or even more

1 Transwaal Agricultural Journal, vol. viii., rgro. "Water Requirements of Crops in India." By J. W. Leather. (Memoirs of the Department of Agriculture in India.) 